\title{
MENJANGKAU ORANG GANGGUAN JIWA DENGAN KONSEP DAUD DALAM 1 SAMUEL 16:23
}

\author{
Oleh : \\ ${ }^{* 1}$ Arthur Sitompul, ${ }^{* 2}$ Bartholomeus Diaz Nainggolan, ${ }^{* 3}$ Stimson Hutagalung \\ Program Pascasarjana Magister Filsafat Universitas Advent Indonesia; \\ Email : *1 arthursitompul@gmail.com, ${ }^{* 2}$ bdnainggolan@yahoo.com, \\ ${ }^{* 3}$ stimson.hutagalung@unai.edu
}

\begin{abstract}
ABSTRAK - Amanat agung yang diberikan Tuhan Yesus untuk menyelamatkan jiwa kepada semua orang adalah tugas yang mulia untuk diemban, tidak terkecuali orang yang mengalami gangguan jiwa juga harus menjadi sasaran untuk dijangkau. Oleh sebab itu tujuan penulisan ini adalah menemukan metode yang efektif untuk menjangkau jiwa orang yang mengalami gangguan jiwa. Metodologi yang digunakan dalam penelitian ini adalah metodologi penelitian kualitatif, dengan pengumpulan data melalui study kasus yaitu observasi lapangan, studi pustaka dan hermeneutik untuk menafsirkan ayat Alkitab yang dijadikan acuan. Hasil yang didapat dalam penelitian ini adalah seorang penginjil dalam usaha menjangkau orang yang mengalami gangguan jiwa maka harus mampu mengerti ilmu jiwa, dengan demikian metode Daud dalam menjangkau Saul yaitu dengan memberi perhatian khusus, pendampingan dan juga pemenuhan kebutuhan dalam usaha memberi kelegaan.
\end{abstract}

Kata Kunci: Gangguan jiwa, Daud, 1 Samuel 16:23

ABSTRACT - The great commision that was given by Jesus Christ to everyone to save the souls is a noble task to be carried out, no exception, for people with mental disorders should also be the target to be reached. Therefore, the purpose of this paper is to explore the effective methode to reach them who are having mental disorders. The method that used in this study is a qualitative methode, by collecting datas through case studies from observationts, literature studies and hermeneutics to interpret the bible verses that are used as references. The results obtained in this study are that an evangelist in an effort to reach people with mental disorders must be able to understand psychology, thus David's method of reaching Saul can be used as the right method.

Keywords: MentalDisorders,, David, 1 Samuel 16:23

\section{PENDAHULUAN}

Menurut definisi WHO, kesehatan bukan hanya keadaan sakit, cacat, dan kelemahan, tetapi keadaan sejahtera fisik, mental, dan sosial. ${ }^{1}$ Akan tetapi realita di dalam kehidupan bermasyarakat, sehat

\footnotetext{
${ }^{1}$ Sekjen Depkes RI, Kumpulan Artikel Pemenang Lomba Karya Tulis Bidang Kesehatan Tahun 19941995 (Jakarta: Depkes RI, 1996), 112.
} 
pada umumnya dimengerti hanya sebatas bebas dari penyakit, dalam hal ini hanya sekedar sehat fisik saja dan mengabaikan faktor-faktor kesehatan yang lain seperti kriteria yang telah di ungkapkan oleh WHO, bahkan orang gangguan jiwa yang secara fisik dapat beraktivitas bebas dianggap sehat secara fisik sehingga tidak jarang luput dari perhatian dan dianggap sebagai kaum marginal.

Gangguan jiwa dapat dipahami sebagai orang dengan gangguan berpikir, perilaku, dan emosional yang terwujud dalam bentuk serangkaian gejala atau perubahan perilaku yang parah yang dapat menyebabkan penderitaan dan gangguan fungsi sebagai manusia biasa. ${ }^{2}$ Sehingga dari pengertian tersebut didapati bahwa sesungguhnya orang gangguan jiwa adalah orang yang sakit, meskipun fisik terlihat baik dan normal.

Menurut penelitian yang dilakukan oleh Imma Dahliyani yang dituangkan dalam jurnalnya yang berjudul Pembinaan Keagamaan Pada Penderita Gangguan Mental Dan Pecandu Narkoba, memberikan informasi bahwa setiap manusia terlahir dengan memiliki kemampuan dan potensi masing-masing, sehingga setiap manusia memiliki kebutuhan psikologis yang tentunya berbeda-beda satu dengan yang lain. ${ }^{3}$ Apabila kebutuhan-kebutuhan yang dibutuhkan manusia tidak terealisasi atau terpenuhi dengan baik maka ini akan mengakibatkan sebuah tekanan sehingga menjadi frustasi yang kemudian bisa

\footnotetext{
${ }^{2}$ Birrell Marwick, Crash Course Psikiatri (Singapore: Elseiver, 2018), 64.

${ }^{3}$ Imma Dahliyani, "Pembinaan Keagamaan Pada

Penderita Gangguan Mental Dan Pecandu

Narkoba," Mudarrisa 5, no. 1 (2013): 1-28.
}

mengakibatkan gangguan jiwa yang meskipun faktor gangguan jiwa banyak hal yang menyebabkannya.

Berdasarkan data yang diperoleh melalui Riset Kesehatan Dasar (Riskesdas) tahun 2007, prevalensi gangguan jiwa emosional pada penduduk usia 15 tahun ke atas di Indonesia sebesar 11,6\%, dan pada tahun 2013 ditemukan 0,17\% (400.000) penduduk secara nasional dengan gangguan jiwa berat secara global, sepertiga penderita gangguan jiwa tinggal di negara berkembang, dan delapan dari sepuluh orang dengan gangguan jiwa tidak diobati. Menurut hasil Survei Kesehatan Rumah Tangga (SKRT) yang dilakukan oleh Badan Penelitian dan Pengembangan di bawah Departemen Kesehatan pada tahun 1995, jumlah remaja dan orang dewasa dengan gangguan jiwa adalah 140 per 1.000 anggota rumah tangga, dan jumlah gangguan jiwa sekolah ada 104 anak usia per 1000 anggota keluarga. ${ }^{4}$ Dari data yang diperoleh melalui riset tersebut dapat dilihat bahwa kasus gangguan jiwa cukup memprihatikan dan membutuhkan perhatian khusus.

Sebagai seorang pendeta, peneliti sesuai dengan metodologinya rindu untuk dapat menjangkau mereka yang mengalami gangguan jiwa tersebut. Mereka adalah orang-orang yang butuh perhatian dan juga berhak untuk mendapatkan keselamatan kekal di dalam Yesus Kristus. Atas kerinduan untuk menyelamatkan jiwa tersebut penulis bersama keluarga, berusaha untuk melakukannya dengan

\footnotetext{
${ }^{4}$ Feri Agung Saputra, Yulius Yusak Ranimpi, and Rama Tulus Pilakoannu, "Kesehatan Mental Dan Koping Strategi Di Kudangan, Kecamatan Delang, Kabupaten Lamandau Kalimantan Tengah: Suatu Studi Sosiodemografi," Humanitas 2, no. 1 (2018): 63-74.
} 
merawat orang yang mengalami gangguan jiwa yang bernama Latifa yang ditemukan di jalan raya kota Cepu. Dengan perhatian yang penuh, memperhatikan kebutuhan jasmani dan rohani, aktif diajak bicara, bernyanyi memuji Tuhan, belajar firman Tuhan dan berdoa, sampai akhirnya Latifa boleh sehat dan pulih kembali.

Matius 28:19-20, "Karena itu pergilah, jadikanlah semua bangsa murid$\mathrm{Ku}$ dan baptislah mereka dalam nama Bapa dan Anak dan Roh Kudus, dan ajarlah mereka melakukan segala sesuatu yang telah Kuperintahkan kepadamu. Dan ketahuilah, Aku menyertai kamu senantiasa sampai kepada akhir zaman." Ayat ini lebih dikenal dengan sebutan "amanat agung" yang berisi suatu perintah Tuhan Yesus Kristus sebelum Dia naik ke Surga, perintahnya adalah untuk menginjil, mewartakan kabar keselamatan, menjangkau semua orang dari berbagai lapisan, suku, budaya dan berbagai latar belakang dengan segala kondisi keadaanya termasuk orang yang mengalami gangguan jiwa.

\section{RUMUSAN MASALAH}

Dalam hal ini penulis akan memaparkan hal-hal yang perlu dibahas sehubungan dengan penjangkauan jiwa terhadap orang yang mengalami gangguan jiwa. Adapaun tujuan penulisan ini adalah untuk mengetahui metode penginjilan yang efektif sehubungan dengan kasus yang muncul yaitu merawat dan menjangkau orang mengalami gangguan jiwa yang tentunya yang akan berdampak juga pada keluarga yang mengalami gangguan jiwa. Sehingga penulisan ini dapat bermanfaat untuk mendapatkan suatu metode secara khusus penginjilan kepada orang yang berkebutuhan khusus, dalam hal ini orang yang mengalami gangguan jiwa.

Teks Alkitab yang dipilih sebagai landasan adalah 1 Sam. 16:23, di mana konteks ayat ini memiliki kemiripan kasus dalam menjangkau orang yang mengalami gangguan jiwa. Peristiwa yang terjadi adalah ketika raja Saul mengalami gangguan jiwa sebab kedudukan sebagai raja akan digantikan. Dalam kasus ini factor penyebab Saul mengalami gangguan jiwa terlihat dari faktor psikis dan sosial, sehingga mengalami beban berat yang menindih sebagai efeknya mengalami gangguan jiwa.

Supaya penulisan ini menjadi sangat terarah maka akan dibuat rumusan masalah sebagai penuntun dengan mengajukan beberapa pertanyaan: Bagaimanakah penjangkauan jiwa kepada orang yang mengalami gangguan jiwa menjadi sangat efektif? Mengapa menjangkau orang yang mengalami gangguan jiwa menjadi sangat penting? Bagaimanakah metode Daud dalam 1 Samuel 16:23 dapat diterapkan dalam menjangkau orang yang mengalami gangguan jiwa?

\section{METODOLOGI PENELITIAN}

Metodologi yang akan digunakan dalam penelitian ini adalah metodologi penelitian kualitatif, yang adalah jenis penelitian yang prosedur statistik dan hasil komputasi lainnya bukanlah acuan pokok, dan bertujuan untuk mengartikulasikan gejala dalam konteks holistik dengan mengumpulkan data dari lingkungan alam. Peneliti sendiri sebagai sarana yang 
penting secara teknis. ${ }^{5}$ Teknik pengumpulan data yang dilakukan penulis adalah dengan cara studi pustaka dari jurnal-jurnal ilmiah dan buku-buku yang terkait dengan pembahasan yang dilakukan. ${ }^{6}$ Penafsiran ayat Alkitab yang digunakan dengan metode hermeneutik yaitu pemahaman atas naskah-naskah Alkitab, termasuk konteks historisnya. ${ }^{7}$ Nast Alkitab yang digunakan dalam Alkitab harus diteliti untuk memahami artinya baik dalam konteks sempit maupun luas.

\section{HASIL DAN PEMBAHASAN}

Berdasarkan study kasus yang pernah dialami oleh penulis, orang yang mengalami gangguan jiwa tersebut berhasil dijangkau, dalam hal ini penulis berhasil menanamkan prinsip keselamatan melalui darah Yesus yang tercurah di kayu salib kepada orang tersebut. Hal tersebut dapat dilakukan dengan terlebih dahulu mengetahui situasi kejiwaan dengan mempelajari seluk beluk dari sumbersumber yang berhubungan dengan ilmu psikologi jiwa dan penerapan dari konsep Daud ketika merawat Saul.

Setiap umat percaya mempunyai peran yang berbeda-beda dalam misi, ${ }^{8}$ tidak terkecuali terhadap orang yang mengalami gangguan jiwa. Untuk dapat

\footnotetext{
${ }^{5}$ Eko Sugiyarto, Menyusun Proposal Penelitian Kualitatif: Skripsi Dan Tesis (Yogyakarta: Suaka Medika, 2015), 8.

${ }^{6}$ Eko Sudarmanto et al., Desain Penelitian Bisnis: Pendekatan Kuantitatif (Medan: Yayasan Kita Menulis, 2021), 45.

${ }^{7}$ W.R.F. Browning, Kamus Alkitab: A Dictionary Of The Bible (Jakarta: Gunung Mulia, 2009), 137.

${ }^{8}$ Bartholomeus Diaz Nainggolan, "KONSEP AMANAT AGUNG BERDASARKAN MATIUS 28:1820 DALAM MISI," Jurnal Koinonia 8, no. 2 (2014): 15-45.
}

menjalankan misi penjangkauan jiwa dengan efektif terhadap orang yang mengalami gangguan jiwa, maka kita perlu mengerti dan memahami tentang gangguan jiwa dengan baik, sehingga kita bisa mengerti seberapa pentingnya penginjilan ini dan metode seperti apa yang efektif untuk dapat digunakan dalam penginjilan dengan kasus seperti ini.

\section{Definisi Gangguan Jiwa}

Menurut Pasal 1 Ayat 3 Kesehatan Jiwa, No. 18 UU RI tahun 2014, pengertian penyakit jiwa dianggap sebagai suatu rangkaian gejala dan/atau rangkaian bentuk yang mengakibatkan kecacatan perilaku dan emosional pada seseorang yang sedang mengalaminya, dan perubahan perilaku yang signifikan yang dapat menyebabkan rasa sakit. ${ }^{9}$

\section{Gejala Gangguan Jiwa}

Secara umum dan mudah dimengerti, bahwa jenis atau pembagian penyakit gangguan jiwa dapat dibagi menjadi dua kelompok: ringan dan berat. Gejala gangguann jiwa sekecil apa pun dapat dilihat pada beberapa manifestasi fisik dan mental, diantaranya sebagai berikut: rasa sedih yang terus menerus, gangguan tidur, sensitifitas emosi, merasa tegang, kegelisahan terjadi, rasa putus asa dan pesimis, gangguan konsentrasi, gangguan somantik, kehilangan minat, lemah, sulit makan atau rakus makan,

\footnotetext{
${ }^{9}$ Anggun Riska Amalita, Nayla Alawiya, and Nurani Ajeng Tri Utami, "Perlindungan Hukum Terhadap Penderita Gangguan Jiwa Dalam Pelayanan Kesehatan Pada Struktur Peraturan PerundangUndangan Indonesia," Soedirman Law Review Universitas Jendral Soedirman 2, no. 1 (2020): 7283.
} 
lebih parah lagi berpikir untuk ingin mati atau bunuh diri. ${ }^{10}$

Bagaimana dengan gejala gangguan jiwa berat? Secara sederhana, gejala gangguan jiwa berat sesungguhnya lebih mudah di kenali sebab gejalanya khas dan mudah dilihat, diantaranya adalah tidak bisa menjalankan kehidupan seharihari, bicara tidak nyambung, sering berperilaku menyimpang, halusinasi dan terkadang mengamuk. ${ }^{11}$ Dalam hal ini, orang gila yang sering kita temui dipinggir-pinggir jalan ataupun tempat lain biasanya mengalami gangguan jiwa berat.

Dari gejala-gejala yang diuraikan diatas, maka dapat dilhat bahwa gangguan jiwa bukanlah hanya sekedar gila, sebab stigma yang muncul dalam masyarakat umumnya bahwa gangguan jiwa adalah orang gila. Namun dari uraian di atas dapat dimengerti sesungguhnya sering sekali, disadari atau tidak disadari manusia yang kelihatannya sehat fisik, akan tapi sesungguhnya banyak yang terganggu jiwanya yang perlu diwaspadai.

\section{Penyebab Gangguan Jiwa}

Ada banyak hal yang dapat menyebabkan gangguan jiwa, oleh sebab itu biasanya penyebab gangguan jiwa tidak terjadi secara tunggal akan tetapi beberapa penyebab sekaligus dari berbagai unsurunsur yang saling berpengruh dan mempengaruhi satu sama lain diantara faktor penyebab tersebut. Fajar Rinawati dan Moh Alimansur dalam jurnal ilmiahnya memberikan informasi bahwa ada tiga faktor utama yang dapat

\footnotetext{
${ }^{10}$ Suryani, "Mengenal Gejala Dan Penyebab Gangguan Jiwa," in Seminar Nasional UNJANI, 2013, 1-11.

11 lbid.
}

menyebabkan orang gangguan jiwa, yaitu biologis, psikologis dan sosial. ${ }^{12}$

Gejala biologis dapat dilihat dari beberapa hal misalnya trauma, penyakit kronis, keturunan. Kelelahan juga bisa menjadi faktor yang memicu stress dari factor biologis. ${ }^{13}$ Dari sisi psikologis penyebabnya diantaranya pengalaman yang tidak menyenangkan, tipe kepribadian orang tersebut, adanya keinginan yang tidak terpenuhi, konsep diri yang negatif, pengasuhan. Faktor sosial bisa terjadi dari adanya konflik baik dalam keluarga atau teman, kehilangan orang yang berarti, tidak mempunyai teman dekat, penghasilan kurang, tidak bekerja dan hal-hal lain yang bisa menyebabkan masalah dalam hidupnya.

\section{Jenis Gangguan Jiwa}

Gangguan jiwa sangat banyak jenisnya. ${ }^{14}$ Namun untuk kepentingan penulisan ini, sesuai dengan pengalaman penulis dalam penjangkauan jiwa atau penginjilan maka akan digali gangguan jiwa jenis depresi dan skizofrenia.

\section{Depresi}

Depresi dapat menyerang siapapun, tanpa memandang usia, baik anak-anak sampai orang tua sekalipun,

\footnotetext{
${ }^{12}$ Fajar Rinawati and Moh Alimansur, "Analisa Faktor-Faktor Penyebab Gangguan Jiwa Menggunakan Pendekatan Model Adaptasi Stres Stuart," Jurnal Ilmu Kesehatan 5, no. 1 (2016): 3438.

${ }^{13}$ Efi Nurwindayani and Eva Nurwiyati, “KONSELING STRES BAGI PENGASUH ANAK BALITA," Jurnal Gamaliel : Teologi Praktika 1, no. 1 (2019): 52-58.

14 Julianto Simanjuntak, Konseling Gangguan Jiwa \& Okultisme: Membedakan Gangguan Jiwa Dan Kerasukan Setan (Jakarta: Gramedia Pustaka Utama, 2008), 7.
} 
tanpa memandang latar belakang juga status sosial. Depresi bisa diartikan sebagai kondisi tekanan (stres) yang sudah berlangsung cukup lama namun belum bisa teratasi, sehingga dapat menenggelamkan psikologis pasien masuk ke dalam rasa kesedihan atau kedukaan yang sangat dalam. ${ }^{15}$ Surveymembuktikan bahwa di Indonesia sendiri, pada tahun 2007 Menurut Fachmi Idris, yaitu ketua Ikatan Dokter Indonesia (IDI), 94\% masyarakat Indonesia mengalami depresi pada level tertinggi dan terendah. Tanda dan Gejala Orang Mengalami Depresi adalah sebagai berikut:

"Berdasarkan Diagnostic and Statistical Manual of Mental Disorder, Fifth Edition (DSM-V), seseorang dikatakan depresi jika setidaknya selama dua minggu mengalami minimal lima dari sembilan kriteria berikut, yaitu (1) adanya perasaan depresi yang muncul di sebagian besar waktu, bahkan hampir setiap hari, (2) adanya penurunan minat dan kesenangan di hampir sebagian besar kegiatan dan hampir setiap hari, (3) adanya perubahan berat badan atau nafsu makan yang signifikan, (4) adanya perubahan tidur: menjadi insomnia atau hipersomnia, (5) adanya perubahan aktivitas, (6) merasa kelelahan dan kehilangan energi, (7) munculnya perasaan bersalah atau tidak berharga yang berlebihan dan sebenarnya tidak pantas muncul, (8) mengalami penurunan konsentrasi, dan (9) memiliki pikiran berulang tentang kematian (tidak hanya takut mati), adanya keinginan bunuh diri berulang tanpa rencana spesifik, usaha bunuh

${ }^{15}$ Dave Alexius, Survivor Care: The 8 Puzzles You Must Know (Yogyakarta: Diandra Kreatif, n.d.), https://books.google.co.id/books?id=61hjDwAAQB AJ\&pg=PA14\&dq=stres + dan+depresi \&hl=ban\&sa= X\&ved=2ahUKEwix9bGfOJ_vAhW94HMBHasNBSsQ 6AEwBnoECAgQAg\#v=onepage $\& q=$ stres dan depresi\&f=false. diri, atau rencana spesifik untuk melakukan bunuh diri." 16

Penyebab dari depresi ada berbagai macam, namun secara garis besar dapat disimpulkan menjadi tiga, yaitu biologi (genetik), sosial yaitu lingkungan dan psikologi. Harvard Health Publication pada tahun 2009 memberikan informasi lebih mendalam tentang penyebab depresi, yaitu banyak hal yang memungkinkan terjadinya depresi termasuk gangguan fungsi otak yang terhubung dengan suasana hati, pengaruh kerentanan genetik, peristiwa-peristiwa kehidupan dengan penuh tekanan atau stres, obat-obatan, dan adanya indikasi medis. ${ }^{17}$ Banyak hal dan masalah dalam kehidupan ini yang membuat orang menjadi depresi. Masalah keluarga, perceraian, ekonomi, sakit tidak sembuh-sembuh, hal-hal ini adalah kejadian yang sering ditemui dalam kehidupan sehari-hari yang tanpa disadari sudah dalam tingkat depresi. Penanganan yang serius harus segera dilakukan supaya tidak menimbulkan efek-efek yang lain, khususya pada penyakit secara fisik. Dalam hal ini untuk mendapatkan pemulihan yang baik maka diperlukanakal budi yang tinggi dalam penanganan suatu penyakit yang disebabkan oleh pikiran.

Menurut Hill, perawatan yang berlaku untuk depresi termasuk terapi keluarga, pelatihan manajemen emosi, hipnosis, pelatihan psikologis, pelatihan berpikir positif, dan terapi perilaku kognitif. Ada banyak perawatan yang tersedia untuk individu yang menderita depresi, tetapi mereka harus dapat

\footnotetext{
${ }^{16}$ Ktut Dianovinina, "Depresi Pada Remaja: Gejala Dan Permasalahannya," Jurnal Psikogenesis 6, no. 1 (2018): 69-78.

17 Ibid.
} 
memberikan perawatan sesuai dengan teori dan pendekatan yang diberikan. ${ }^{18}$

Ada korelasi yang kuat antara penyakit medis kronis dan peningkatan gangguan depresi. Depresi yang berlanjutan tanpa penanganan yang serius akan bisa mengakibatkan gangguan kesehatan fisik yang serius. Organ-organ tubuh tidak akan bekerja dengan normal dan teratur. Hal itu dapat dianalisa dari orang yang depresi akan terjadi gangguan pola tidur dan makan. Maka dalam kondisi seperti ini perlu diadakan pendampingan untuk dapat menyelesaikan masalah dengan baik. ${ }^{19}$

\section{Skizofrenia}

Gangguan jiwa yang sering ditemui berikutnya adalah skizofrenia yang pengertian banyak orang menyebutnya "gila". Skizofrenia adalah bentuk serius dari penyakit mental di mana penyakit ini sulit untuk membedakan antara apa yang nyata dan apa yang tidak, sehingga akibatnya adalah kehilangan kontak dengan kenyataan. ${ }^{20}$ Ciri-ciri reaksi ini ditandai dengan pengunduran dari kehidupan sosial dalam bermasyarakat, memiliki gangguan emosional yang tidak stabil, dan kemudian disertai dengan gejala halusinasi (ciri khas) dan delusi serta tidak jarang ditambah dengan perilaku yang

\footnotetext{
${ }^{18}$ Widiya Aris Radiani, “Cognitive Behavior Therapy Untuk Penurunan Depresi Pada Orang Dengan Kehilangan Penglihatan," InSigh 18, no. 1 (2016): 66-82.

${ }^{19}$ Stimson Hutagalung et al., Konseling Pastoral (Medan: Yayasan Kita Menulis, 2021), 94.

${ }^{20}$ Agung Wahyudi and Arulita Ika Fibriana, "Faktor Resiko Terjadinya Skizofrenia," Public Health Perspective Journal 1, no. 1 (2016): 1-12.
}

negatif ataupun merusak. ${ }^{21}$ Sehingga tidak aneh kalau orang pada umumnya lebih tahu dan mengenal gangguan jiwa ini dengan sebutan gila seperti yang telah diungkapkan di atas, oleh sebab kelakuannya yang tidak stabil.

Menurut data yang diperoleh kasus skizofrenia di Indonesia cukup memprihatinkan dan membutuhkan perhatian yang lebih serius. Di tahun 2007, prevalensi skizofrenia di negara Indonesia adalah 2 per mil. Namun, menurut WHO, data menunjukkan bahwa prevalensi skizofrenia di Indonesia meningkat 2,6 mil di tahun 2013. ${ }^{22}$ Dengan demikian peningkatan jumlah penderita skizofrenia perlu diwaspadai, sebab dari tahun ke tahun adanya peninggkatan jumlah. Penelitian lebih jauh lagi dengan skala internasional, diantara penderita skizofrenia di seluruh dunia, 20-50\% orang pernah mencoba utuk bunuh diri, dan $10 \%$ meninggal oleh sebab bunuh diri. Tingkat kematian pasien dengan skizofrenia adalah 8 kali lebih tinggi dari populasi umum. ${ }^{23}$

Gangguan jiwa skizofrenia tidak begitu saja dengan mudah terjadi, bahkan terjadi dengan sendirinya, ada tahapan atau proses dan faktor - faktor yang saling berkaitan satu sama lain. Banyak faktor itulah yang akan berperan terhadap kejadian skizofrenia. Faktor-faktor tersebut yang sangat berperan terhadap kejadian skizofrenia antara lain faktor genetik, biologis, biokimia, psikososial, status

\footnotetext{
${ }^{21}$ Simanjuntak, Konseling Gangguan Jiwa \& Okultisme: Membedakan Gangguan Jiwa Dan Kerasukan Setan, 8.

22 Wahyudi and Fibriana, "Faktor Resiko Terjadinya Skizofrenia."

23 Ibid.
} 
sosial ekonomi, stress, serta penyalahgunaan obat. ${ }^{24}$

Problem yang sering terjadi di masyarakat sehingga menimbulkan efek negatif adalah minimnya pengetahuan dan pendidikan, secara khusus dari pihak keluarga yang menderita skizofrenia. Anggapan bahwa orang menderita gangguan jiwa ini tidak memiliki masa depan sehingga sikap yang tejadi adalah sikap negatif, bahkan lebih sadis dipasung sampai dikurung dalam kandang seperti binatang. Sebenarnya, sikap yang seperti ini justru memiliki dampak dan efek yang sangat buruk kepada penderita, disamping tidak memiliki sifat kemanusiaan maka akan menambah penderita lebih menderita lagi. Lebih uniknya lagi bahwa ada anggapan bahwa gangguan jiwa ini disebabkan oleh makhluk halus atau santet atau guna-guna, dan tidak jarang mencari pengobatan kepada dukun. Menurut penelitian yang dilakukan oleh Hardiman dan Umi didapati bahwa upaya pencarian kesembuhan penderita gangguan mental seperti ini dari 99 sampel yang didapat, ternyata tempat pertama kali yang dikunjungi adalah dukun. ${ }^{25}$

\section{Gangguan jiwa dan Peluang Injil}

Dalam kerangka teori telah dibahas dua gangguan jiwa yang sering ditemukan di lingkungan masyarakat umum yaitu depresi dan skizofrenia. Berdasarkan penelitian yang dilakukan oleh Lubis, Krisnani dan Fedryansyah, bahwa orang yang mengalami gangguan

\footnotetext{
${ }^{24}$ Siti Zahnia and Dyah Wulan Sumekar, "Kajian Epidemiologis Skizofrenia," Majority 5, no. 4 (2016): 160-166.

${ }^{25}$ Simanjuntak, Konseling Gangguan Jiwa \& Okultisme: Membedakan Gangguan Jiwa Dan Kerasukan Setan, 9.
}

jiwa dapat disembuhkan. Dengan mengetahui faktor-faktor penyebabnya akan memudahkan untuk sebuh dengan terapi yang diberikan kepada orang yang mengalami gangguan jiwa tersebut dengan tepat. $^{26}$ Ambari dalam penelitiannya menyatakan bahwa dukungan keluarga memiliki peran yang sangat penting bagi pasien skizofrenia dalam hidup bersosial. Semakin tinggi tingkat perhatian dan dukungan, maka akan semakin tinggi peluang urntuk hidup bersosial dengan baik. $^{27}$ Dari dua penelitian ini dapat dimengerti bahwa kebutuhan orang gangguan jiwa adalah perhatian yang khusus dengan menggunakan bahasa kasih yang penuh dengan kelamah lembutan, sehingga komunikasi dan kesadaran diri dapat terbangun, dengan demikian peluang untuk menerima injil sangat terbuka.

\section{Samuel}

Kitab 1 Samuel diawali dengan kisah dari tokoh terkenal, ternama dan dihormati dikalangan orang Israel, yaitu Samuel. Penulis kitab ini kurang jelas siapa penulisnya, namun para ahli meyakin bahwa Samuel juga ikut berperan dalam penulisan kitab ini sebelum kematiannya. Dalam kitab Samuel lebih berfokus pada

\footnotetext{
${ }^{26}$ Nadira Lubis, Hetty Krisnani, and Muhammad Fedryansyah, "Pemahaman Masyarakat Mengenai Gangguan Jiwa Dan Keterbelakangan Mental," PROSIDING KS: RISET \& PKM 2, no. 3 (2015): 201444.

27 Prinda Kartika Mayang Ambari, HUBUNGAN ANTARA DUKUNGAN KELUARGA DENGAN KEBERFUNGSIAN SOSIAL PADA PASIEN SKIZOFRENIA PASCA PERAWATAN DI RUMAH SAKIT (Semarang: Fakultas Psikologi UNDIP, 2010), http://eprints.undip.ac.id/10956/.
} 
tiga tokoh utama orang Israel, yatiu Samuel, Daud dan Saul. ${ }^{28}$

Kitab Samuel berisi tentang situasi yang terjadi di Israel, di mana moral yang sangat merosot dari bangsa Israel dan Israel dilihat sebagai bangsa yang lemah apbila dibandingkan dengan bangsa-bangsa kafir yang tinggal disekitarnya. Di zaman inilah terjadi transisi sistem pemerintahan yaitu dari zaman hakim-hakim menjadi sistem bersifat monarki, raja yang memimpin dan berkuasa. Maka kitab 1 Samuel memberikan informasi yang lengkap tentang pembaharuan atau reformasi bangsa Israel. Dengan demikian, penulisan kitab Samuel ini memiliki tujuan memaparkan sejarah peralihan kepemimpinan hakim-hakim menjadi kerajaan, antara Samuel dengan Saul. ${ }^{29}$

\section{Samuel 16}

Pasal 16 dari kitab 1 Samuel dari kitab versi terjemahan baru, terdiri dari 23 ayat yang terbagi menjadi dua perikop yang menceritakan latar yang berbeda. Kisah pertama (1 Sam. 16:1-13) terjadi di rumah Daud, di mana Samuel diutus Tuhan untuk memilih orang pilihannya yang akan menggantikan Saul sebagai raja. Perikop yang kedua (1 Sam. 16:14-23) adalah berkisah tentang proses orang pilihan Tuhan, yang telah diurapi Tuhan melalui Samuel, yaitu Daud sampai dan berada di istana Saul, yang mana kondisi Saul dalam keadaan kurang baik, sedang mengalami gangguan jiwa.

\footnotetext{
${ }^{28}$ Dian Agustina, Yeni Anita Pattinama, and Febriaman Lalaziduhu Harefa, "Spiritualitas Hana Menurut 1 Samuel 1:1-28 Dan Implementasimya Bagi Wanita," Jurnal Scripta Teologi dan Pelayanan 1, no. 1 (2020): 1-19.

${ }^{29}$ Ibid.
}

\section{Samuel 16:14-23}

1 Samuel 16:14-23 berisi kisah antara Daud dan Saul. Dalam perikop ini dibagi menjadi tiga setting lokasi yang membentuk sebuah narasi. Setting lokasi tersebut yaitu: pertama, di istana Saul (1 Sam. 16:14-18), di mana di lokasi pertama ini terjadi percakapan antara Saul dengan pegawainya mengenai apa yang sedang di alami Saul, yaitu Saul di ganggu roh jahat sebab Roh Tuhan telah meninggalkan Saul. Pada percakapan ini pegawai Saul menyarankan untuk mencari orang yang pandai bermain kecapi untuk mengusir roh jahat apabila datang. Kedua, di rumah Isai, ayah Daud (1 Sam. 16:19-20). Di sini Isai menerima utusan Saul dengan baik dan menjamunya dengan baik. Di istana Saul (1 Sam. 16:21-23). Daud tiba di istana saul dan diakhiri dengan sebuah kelegaan bagi Saul ketika Daud memainkan kecapinya.

\section{Pengalaman Daud}

Teks yang akan dibahas sebagai metode ataupaternpenginjilan terhadap orang gangguan jiwa adalah 1 Sam 16:23, maka untuk memahami metode ini, maka akan dilihat latar belakang teks tersebut dan akan dilakukan exegesis terhadap teks tersebut.

\section{Latar Belakang Teks 1 Sam 16:23}

Teks ini dilatarbelakangi dari pasal sebelumnya yaitu pasal 15 dari kitab 1 Samuel. Pasal dalam kitab ini diawali intruksi Allah melalui Samuel sebagai utusan Allah kepada Saul raja Israel pertama yang dipilih Allah. Intruksi Allah kepada Saul melalui Samuel adalah untuk menumpas orang Amalek tanpa menyisakan apapun (1 Sam 15:2-3). Namun pada prakteknya, raja Saul tidak 
menjalankan perintah itu sepenuhnya dengan menyisakan Agag raja orang Amalek, yang tidak dibunuh sesuai intruksi Allah melainkan ditangkap hidup-hidup. Bukan hanya menangkap raja orang Amalek itu, Saul juga menyisakan hewanhewan ternak yang bagus dan barangbarang yang berharga (1 Sam 15:9) dengan alasan hewan ternak yang terbaik untuk menjadi persembahan bagi Tuhan (1 Sam 15:21)

Apapun alasannya, Saul tidak mengindahkan perintah Tuhan dengan baik sehingga menimbulkan murka Tuhan. Tuhan Allah mengutus Samuel untuk bertemu dengan Saul dengan membawa pesan murka Allah kepada Saul, "Kemudian berkatalah Samuel kepadanya: "TUHAN telah mengoyakkan dari padamu jabatan raja atas Israel pada hari ini dan telah memberikannya kepada orang lain yang lebih baik dari padamu." (1 Sam 1Fg5:28) Saul akan diturunkn sebagai seorang Raja dan akan digantikan orang yang berasal dari bukan keturunannya. Sejak saat itu Allah tidak berkenan lagi kepada Saul dan Allah tidak bersama lagi dengan Saul, dengan demikian inilah detikdetik akhir kekuasaan Saul.

Apa yang terjadi dengan Saul setelah mendengar berita penghukuman itu dari Samuel? Ellen G. White memberikan komentar mengenai kondisi psikis Saul setelah mendengar berita tersebut:

"Pada waktu Saul menyadari bahwa dia telah ditolak oleh Allah, ia dipenuhi oleh kecewaan dan pemberontakan yang getir. Ia terus memikir-mikirkan apa yang ia rasa sebagai ketidak adilan Allah dalam menyisihkan dia dari takhta kerajaan Israel dan dengan mengambil penggantinya bukan dari keturunannya. Ia senantiasa memikirmikirkan kehancuran yang telah menimpa rumah tangganya. Ia tidak menerima dengan rendah hati hukuman Allah itu, tetapi rohnya yang congkak itu menjadi kecewa sekali, sehingga hampir-hampir ia kehilangan akal. Para penasehatnya menganjurkan agar ia mencari bantuan dari seorang ahli musik, dengan pengharapan bahwa lagu-lagu yang merdu dari satu alat musik akan dapat menenangkan pikirannya yang kacau." 30

\section{Exegesis 1 Sam 16:23}

Isi teks 1 Sam 16:23 "Dan setiap kali apabila roh yang dari pada Allah itu hinggap pada Saul, maka Daud mengambil kecapi dan memainkannya; Saul merasa lega dan nyaman, dan roh yang jahat itu undur dari padanya." Teks ini memuat prinsip sebab dan akibat, yaitu perasaan lega dan nyaman yang adalah satu paket, dan roh jahat hilang oleh sebab mendengarkan permainan kecapi. Dalam teks ini diasumsikan bahwa roh jahat itu berasal dari Allah yang sesuai dengan kalimat awal di ayat tersebut. Untuk mengerti dengan baik teks tersebut akan di exegesis dua kata kunci dari teks tersebut yaitu "Lega dan Nyaman" dan "Roh Jahat."

\section{Lega dan Nyaman}

"Lega dan nyaman" dalam teks 1

Samuel 16:23 berasal dari dua kata dalam teks Ibrani yaitu רוב (tồbach) dan Kata רות (râvach) artinya "bernafas dengan mudah, lega" Kata רוז (râvach) yang dipakai dalam teks tersebut berasal dari akar kata 7 (rûach) yang artinya "senang atau gembira." Kata berikutnya adalah טוב

\footnotetext{
${ }^{30}$ Ellen G. White, Sejarah Para Nabi Jld. 2, 2021, 291, egwwritings.org.
} 
(tôb) yang artinya dalam keadaan baik, menyenangkan, sukacita, gembira. Dengan demikian dapat kita mengerti kata "Lega dan nyaman" dalam teks 1 Samuel 16:23 adalah suatu kondisi yang berhubungan dengan situasi yang sedang dialami oleh Raja Saul secara fisik, hati maupun pikiran, yaitu suatu suasana hati yang senang atau gembira yang ditandai dengan gejala fisik dapat bernafas dengan mudah atau lega.

Menurut keterangan exegesis teks 1 Samuel 16:23 tentang "Lega dan nyaman", diindikasikan bahwa Saul pada mulanya sedang tidak gembira atau sedang sedih hati yang ditandai denga gejala ritme nafas yang tidak baik, namun setelah mendengarkan musik dari Daud yang membuat teduh hatinya, sehingga dia menjadi lega dan nyaman. Stres atau tekanan membuat hati bersedih. Diah Ayu Lestari dalam artikelnya yang dimuat dalam situs National Geographic Indonesia menjelaskan bahwa stres atau tekanan dapat mempengaruhi fungsi tubuh termasuk menimbulkan sesak nafas meskipun tidak menderita atau memiliki penyakit gangguan pernafasan. ${ }^{31}$

\section{Roh Jahat}

Kata "roh jahat" dalam teks ini berasal dari dua kata bahasa ibrani yaitu yang pertama adalah רוּ (rûach: roh) dan menariknyakata ibrani yang digunakan di sini untuk menyebut "roh" sama dengan akar kata yang digunakan dalam kata

\footnotetext{
${ }^{31}$ Diyah Ayu Lestari, "Stres Bisa Membuat Seseorang Sesak Napas, Apa Alasannya?," National Geographic, last modified 2021, accessed March 9, 2021,

https://nationalgeographic.grid.id/read/13187592 5/stres-bisa-membuat-seseorang-sesak-napas-apaalasannya.
}

"lega" pada kata sebelumnya dalam teks yang sama yang memiliki arti "senang, gembira." Namun kata ini disandingkan dengan kata kedua yaitu kata רעהרע ( râ'ahh) yang berakar kata רע (râ'a') yang artinya "menghancurkan, menjadi buruk." Dengan demikian bilamana di ambil pengertian secara lebih luas kata "roh jahat" dapat dimengerti sebagai "kebahagiaan yang hancur." Sehingga dalam konteks ini makna kata "roh jahat" dapat disimpulkan sebagai suatu suasana hati yang tidak enak, dan sedang mengalami kesedihan.

\section{Aplikasi}

Dari latar belakang dan exegesis yang telah dibuat dari 1 Sam 16:23 dapat diaplikasikan sebagai berikut: "Dan setiap kali apabila roh yang dari pada Allah itu hinggap pada Saul, maka Daud mengambil kecapi dan memainkannya; Saul merasa lega dan nyaman, dan roh yang jahat itu undur dari padanya." Dapat diterapkan menjadi seperti berikut, "Dan setiap kali rasa sedih oleh karena mengingat hukuman Allah ada pada Saul, maka Daud mengambil kecapi dan memainkannya; Saul merasa gembira sehingga bisa bernafas lega, dan kesedihan, perasaan yang hancur itu hilang dari pada Saul. "Dengan demikian, sesungguhnya Saul sedang mengalami gangguan jiwa, kesedihan hati yang berkepanjangan dan membutuhkan penghiburan.

Konsep yang terbangun dari kisah ini adalah orang yang mengalami gangguan jiwa, seperti Saul sesungguhnya membutuhkan orang yang mengerti keadaan batinnya yang mampu memberikan penghiburan sehingga mendapatkan sebuah ketenangan hati. 
Seorang gembala seharusnya berperan menjadi Daud modern yang memberikan kelegaan kepada domba-dombanya yang mengalami gangguan jiwa. Kata "lega" menurut kamus besar Bahasa Indonesia dapat diartikan sebagai perasaan yang tenang, tentram dan tidak gelisah. ${ }^{32}$ Dengan demikian seorang gembala dan juga anak-anak Tuhan dapat memberikan kelegaan yaitu berupa sebuah ketenangan, ketentraman hati dan menghilangkan rasa gelisah kepada orang yang mengalami gangguan jiwa tersebut. Cara atau usaha yang dapat dilakukan dengan memberikan perhatian khusus, perhatian yang penuh kasih dan kelemah lembutan, memperhatikan kebutuhan, dan berusaha mengarahkan kehidupan orang tersebut kepada Sang Pencipta dengan mengajak berdoa. hal seperti inilah yang merupakan cara atau metode dalam mengimplementasikan amanat agung Tuhan Yesus Kristus dalam sebuah upaya memenangkan jiwa. Seorang gembala harus mampu menjalankan perannya sebagai seorang pelindung dan menciptakan kondisi emosi yang nyaman terhadap umat yang mengalami gangguan jiwa. Dengan demikian seperti merawat dan mendidik seorang anak, demikianlah harusdi perlakukan, sehingga dalam disiplin yang penuh kesabaran dan konsisten di harapkan akan ada perubahan yang lebih baik. ${ }^{33}$

\footnotetext{
32 Ebta Setiawan, "Kamus Besar Bahasa Indonesia Online," Badan Pengembangan Dan Pembinaan Bahasa (Pusat Bahasa), last modified 2021, accessed September 1, 2021, https://kbbi.web.id/lega.

${ }^{33}$ Aby Gayel, Stimson Hutagalung, and Rolyana Ferinia, "Tantangan Mendidik Anak-Anak Pendeta Di Gereja Masehi Advent Hari Ketujuh (GMAHK) DKI Jakarta Melalui Penerapan Disiplin Dan
}

\section{KESIMPULAN}

Upaya penjangkauan jiwa terhadap orang yang mengalami gangguan jiwa menjadi sangat penting sekali, sebab menurut pemaparan di atas bahwa sesungguhnya gangguan jiwa adalah sebuah penyakit yang membutuhkan pengobatan. Orang yang mengalami gangguan jiwa, khususnya gangguan jiwa berat bukanlah orang yang tanpa harapan dan tidak memiliki masa depan, namun sebaliknya penjangkauan yang efektif akan memberikan sebuah harapan bagi orang yang mengalami gangguan jiwa dan keluarganya sehingga mampu mencegah efek-efek negatif. Orang-orang seperti ini juga berhak untuk mendapatkan keselamatan dan mereka juga berhak menerima Injil kekal. Injil kekal, keselamatan di berikan untuk semua orang dengan latar belakang apapun, maka upaya penjangkauan ini menjadi sangat penting.

Untuk menjadi lebih efektif dalam upaya penjangkauan jiwa, maka seorang gembala ataupun anak-anak Tuhan harus mampu mengetahui kebutuhan kejiwaan dari orang yang mengalami gangguan jiwa dengan belajar dan mau mengerti tentang ilmu jiwa. Maka dengan demikian pegalaman Daud dalam mengerti kebutuhan kejiwaan Saul dapat diterapkan dengan baik dan efektif dalam penjangkauan jiwa terhadap orang yang mengalami gangguan jiwa. Maka penerapan yang dapat dilakuakn didunia modern ini adalah dengan memberikan perhatian secara khusus, melakukan pendampingan dalam upaya pemulihan emosi, mental dan psikisnya. Berkomunikasi aktif dan memotivasi orang

Keteladanan," EDULEAD: Journal of Christian Education and Leadership 2, no. 1 (2021): 102-119. 
yang mengalami gangguan jiwa dengan harapan menumbuhkan semangat dan

\section{REFERENSI}

Aby Gayel, Stimson Hutagalung, and Rolyana Ferinia. "Tantangan Mendidik Anak-Anak Pendeta Di Gereja Masehi Advent Hari Ketujuh (GMAHK) DKI Jakarta Melalui Penerapan Disiplin Dan Keteladanan." EDULEAD: Journal of Christian Education and Leadership 2, no. 1 (2021): 102-119.

Agustina, Dian, Yeni Anita Pattinama, and Febriaman Lalaziduhu Harefa. "Spiritualitas Hana Menurut 1 Samuel 1:1-28 Dan Implementasimya Bagi Wanita." Jurnal Scripta Teologi dan Pelayanan 1, no. 1 (2020): 1-19.

Alexius, Dave. Survivor Care: The 8 Puzzles You Must Know. Yogyakarta: Diandra Kreatif, n.d. https://books.google.co.id/books?id=6 1 hjDwAAQBAJ\&pg=PA14\&dq=stre $\mathrm{s}+$ dan+depresi\&hl=ban $\& \mathrm{sa}=\mathrm{X} \& \mathrm{ved}=$ 2ahUKEwix9bGf0J_vAhW94HMBH asNBSsQ6AEwBnoECAgQAg\#v=on epage \&q=stres dan depresi\&f=false.

Amalita, Anggun Riska, Nayla Alawiya, and Nurani Ajeng Tri Utami.

"Perlindungan Hukum Terhadap Penderita Gangguan Jiwa Dalam Pelayanan Kesehatan Pada Struktur Peraturan Perundang-Undangan Indonesia." Soedirman Law Review Universitas Jendral Soedirman 2, no. 1 (2020): 72-83.

Ambari, Prinda Kartika Mayang. HUBUNGAN ANTARA DUKUNGAN KELUARGA DENGAN KEBERFUNGSIAN SOSIAL PADA PASIEN SKIZOFRENIA PASCA PERAWATAN DI RUMAH SAKIT. Semarang: Fakultas Psikologi UNDIP, 2010. http://eprints.undip.ac.id/10956/. Browning, W.R.F. Kamus Alkitab: A Dictionary Of The Bible. Jakarta: pikiran positif, terlebih berdoa untuk mengarahkan hidup kepada Sang Pencipta. Gunung Mulia, 2009.

Dahliyani, Imma. "Pembinaan Keagamaan Pada Penderita Gangguan Mental Dan Pecandu Narkoba." Mudarrisa 5, no. 1 (2013): 1-28.

Dianovinina, Ktut. "Depresi Pada Remaja: Gejala Dan Permasalahannya." Jurnal Psikogenesis 6, no. 1 (2018): 69-78.

Hutagalung, Stimson, Bartholomeus D Nainggolan, Alvyn Cesarianto Hendriks, Yane Restuwati Walukouw, Reymand Hutabarat, Ester Karosekali, Freddy Manurung, et al. Konseling Pastoral. Medan: Yayasan Kita Menulis, 2021.

Lestari, Diyah Ayu. "Stres Bisa Membuat Seseorang Sesak Napas, Apa Alasannya?" National Geographic. Last modified 2021. Accessed March 9, 2021.

https://nationalgeographic.grid.id/read /131875925/stres-bisa-membuatseseorang-sesak-napas-apa-alasannya.

Lubis, Nadira, Hetty Krisnani, and Muhammad Fedryansyah.

"Pemahaman Masyarakat Mengenai Gangguan Jiwa Dan Keterbelakangan Mental." PROSIDING KS: RISET \& PKM 2, no. 3 (2015): 201-444.

Marwick, Birrell. Crash Course Psikiatri. Singapore: Elseiver, 2018.

Nainggolan, Bartholomeus Diaz.

"KONSEP AMANAT AGUNG BERDASARKAN MATIUS 28:1820 DALAM MISI." Jurnal Koinonia 8, no. 2 (2014): 15-45.

Nurwindayani, Efi, and Eva Nurwiyati. "KONSELING STRES BAGI PENGASUH ANAK BALITA." Jurnal Gamaliel : Teologi Praktika 1, no. 1 (2019): 52-58.

Radiani, Widiya Aris. "Cognitive Behavior Therapy Untuk Penurunan Depresi Pada Orang Dengan Kehilangan Penglihatan." InSigh 18, no. 1 (2016): 66-82. 
Rinawati, Fajar, and Moh Alimansur.

"Analisa Faktor-Faktor Penyebab

Gangguan Jiwa Menggunakan

Pendekatan Model Adaptasi Stres

Stuart." Jurnal Ilmu Kesehatan 5, no. 1 (2016): 34-38.

Saputra, Feri Agung, Yulius Yusak

Ranimpi, and Rama Tulus

Pilakoannu. "Kesehatan Mental Dan

Koping Strategi Di Kudangan,

Kecamatan Delang, Kabupaten

Lamandau Kalimantan Tengah: Suatu

Studi Sosiodemografi." Humanitas 2,

no. 1 (2018): 63-74.

Sekjen Depkes RI. Kumpulan Artikel

Pemenang Lomba Karya Tulis Bidang

Kesehatan Tahun 1994-1995. Jakarta:

Depkes RI, 1996.

Setiawan, Ebta. "Kamus Besar Bahasa

Indonesia Online." Badan

Pengembangan Dan Pembinaan

Bahasa (Pusat Bahasa). Last

modified 2021. Accessed September

1, 2021. https://kbbi.web.id/lega.

Simanjuntak, Julianto. Konseling

Gangguan Jiwa \& Okultisme:

Membedakan Gangguan Jiwa Dan

Kerasukan Setan. Jakarta: Gramedia

Pustaka Utama, 2008.

Sudarmanto, Eko, Ardhariksa Zukhruf

Kurniullah, Erika Revida, Rolyana

Ferinia, Marisi Butarbutar, Leon A

Abdilah, Andriasan Sudarso, et al.

Desain Penelitian Bisnis: Pendekatan

Kuantitatif. Medan: Yayasan Kita

Menulis, 2021.

Sugiyarto, Eko. Menyusun Proposal

Penelitian Kualitatif: Skripsi Dan

Tesis. Yogyakarta: Suaka Medika, 2015.

Suryani. "Mengenal Gejala Dan Penyebab

Gangguan Jiwa." In Seminar Nasional

UNJANI, 1-11, 2013.

Wahyudi, Agung, and Arulita Ika Fibriana.

"Faktor Resiko Terjadinya

Skizofrenia." Public Health

Perspective Journal 1, no. 1 (2016):

$1-12$.
White, Ellen G. Sejarah Para Nabi Jld. 2, 2021. egwwritings.org.

Zahnia, Siti, and Dyah Wulan Sumekar. "Kajian Epidemiologis Skizofrenia." Majority 5, no. 4 (2016): 160-166. 